\title{
Intramucosal Lesion
}

National Cancer Institute

\section{Source}

National Cancer Institute. Intramucosal Lesion. NCI Thesaurus. Code C60663.

A pathologic process that is confined to the mucosa. 